\title{
National Securitization Strategy?
}

Alexander V. Solovyov

\author{
Alexander V. Solovyov \\ Russia in Global Affairs \\ Deputy Editor-in-Chief \\ SPIN RSCI: $7701-8673$ \\ ORCID: 0000-0003-2897-0909 \\ ResearcherID: Y-6177-2018 \\ E-mail: a.soloviev@globalaffairs.ru \\ Tel.: (+7) 4959807353 \\ Address: Foreign Policy Research Foundation, 623, Moscow 119049, Russia. \\ DOI: $10.31278 / 1810-6374-2021-19-3-164-172$
}

S

tate policy documents on the country's key political goals and objectives naturally attract the attention of political and international relations experts. The National Security Strategy of the Russian Federation, adopted on July 2, 2021, is no exception. And since the matter at hand is security, it seems interesting to consider the provisions of this document through the lens of the securitization theory, which was proposed by B. Buzan and O. Wæver in the mid1990s and since then has steadily been gaining significance. This looks especially relevant because for Russian research the security dimension of domestic and international processes traditionally comes first compared to their other aspects.

Securitization implies, above all, discourse analysis, and in this regard the Strategy offers high-quality material since, firstly, it is the successor to similar documents adopted earlier, and secondly, being a classic speech act, it officially identifies the concepts of threats and 
securitization objects, that is, structures, institutions or categories that are exposed to these threats.

The Strategy uses two concepts: "threats" proper and "negative factors," which "create a direct or indirect possibility for damaging national interests" (Strategy, 2021). Therefore, the key objects of securitization in the Strategy are the national interests of Russia (which is quite in line with the traditional security discourse: "For a state, survival is about sovereignty, and for a nation it is about identity" (Buzan, and de Wilde, 1998, p. 36)). Not to mention the fact that "national interest" is a key category for the Realist school of international relations, which dominates Russian academic and practical discussions. However, the authors of the securitization concept interpret the notion of security much broader: in principle, any object can be securitized (Ibid). The authors of the Strategy also approach the security problem extensively, but in a slightly different way.

They extend the concept of threat that Buzan and Wæver limited to existential threats to securitization objects (Ibid., 1998, p. 5). Obviously, a "negative factor" can hardly be considered an existential threat. More likely, according to the Buzan-Wæver's concept, "negative factors" are the result of activity (or activity itself) by various functional actors which affect the dynamics of a sector (Ibid, p. 36).

So, the official Russian discourse and the Strategy define economic sanctions against Russia not as a threat to the national economy, but as a negative factor; the same applies, for example, to environmental problems, to the low qualification of medical workers, and to the level of education (except for the quality of teaching of the Russian language, the deterioration of which is recognized as a threat). Threats are, for example, the activities of foreign intelligence and special services, "the activities of foreign and international non-governmental organizations... aimed at violating the unity and territorial integrity of the Russian Federation," "the eroding of traditional Russian spiritual and moral values and the weakening of the unity of the multinational people of the Russian Federation through external cultural and information expansion," etc. (Strategy, 2021). 
However, the "total sum of fears" itself may well be existential in nature due to the scale formed by simple addition. The total number of threats mentioned in the Strategy and "factors that negatively affect security" is approaching one hundred. The mere listing of them shows both the gravity of security challenges and the fact that the state is its only guarantor. One of the most frequently mentioned ways of ensuring security is state control and supervision in various areas, and the "strengthening of the role of the state as a security guarantor" tops the list of "the main areas of national and public security."

A self-sustaining system of "sustainable securitization" is thus created, in which the political authorities that have monopolized the security discourse determine the nomenclature of threats that goes far beyond traditional dangers involving the use of force, set priorities for combating these threats, and assess the results of this work. At the same time, unlike the theoretical Buzan-Wæver model, which considers desecuritization "the optimal long-range option" (Buzan, Wæver and de Wilde, 1998, p. 29), the state is generally not interested in desecuritizing such threats.

Perhaps the problem is that desecuritization implies bringing the issue from the field of security and emergency measures back into the field of "normal" politics, that is, to the sphere where a democratic society (theoretically) can challenge the state's monopoly on decisionmaking (Makarychev, 2008, p. 26). It seems that the state views this possibility as a threat that undermines its ability to mobilize (or demobilize) society, and exercise control and supervision. In other words, it is the prospects for desecuritization themselves and the possibility not just to ensure security, but to remove the issue of security from the agenda that are securitized.

In fairness, such fears are characteristic not only of the Russian political leadership. The "sustainable securitization" effect has been registered as part of the Cold War-era bloc confrontation (Webber and Sperling, 2017, p. 27) in health care (McInnes and Rushton, 2011), etc. Moreover, "sustainable securitization" is not the sole prerogative of states because society (or its parts) is also capable of such a reaction (Risør, 2018). This should prompt theoreticians to study 
the securitization mechanism not only as a single (and completedsuccessful or failed) discursive act or a combination of such acts, but also as a process stretched in time (including infinitely). The COVID-19 pandemic will apparently spur this research. Google Scholar search has returned almost 7,000 articles in English alone, which explore different aspects of securitization in light of the current pandemic.

Among other notable aspects of the Strategy, it is perhaps worth noting a certain convergence of exogenous and endogenous threats. Just recently, it was almost an axiom that the modern "sovereign territorial state" clearly divides "the political sphere into domestic and foreign policy" (Morozov, 2011, p. 29), and that "the security discourse is focused on strengthening a community's borders in the face of external threats" (Ibid., 32). However, today threats are "complex and interconnected," and although the "Russia in the Modern World" section focuses mainly on external threats, "substantive" sections refer mainly to internal and "hybrid" ones ranging from a technological lag to corruption, and from the dwindling prestige of the teaching and engineering professions to depletion of natural resources. In fact, in 1979, the first full-time President of the Council on Foreign Relations, Bayless Manning, coined the term 'Intermestic' to describe the intersection of domestic and foreign policies (Manning, 1979). In the information era, when communication has become transboundary and political activity is supranational and non-state, the emergence of mixed endogenous and exogenous threats is inevitable.

Naturally, strategic international security issues form a separate section in the Strategy and are practically not interconnected with the domestic political agenda. Moreover, this section is quite constructive in content, with the repeatedly stated "red lines" (deterrence and NATO's unacceptable infrastructure expansion) reappearing in the very end. As a rule, there is little ambiguity about securitizing actors in the military sector. Relative and absolute military capabilities do not determine securitization, although they can facilitate it (Buzan, Wæver and de Wilde, 1998, p. 70).

Much more significant-judging by the official activity unfolding in the context of the Strategy-are the threats of "eroding traditional 
Russian spiritual and moral values... through external cultural and information expansion" and "attempts to falsify Russian and world history." Less than a month after signing the decree endorsing the Strategy, President Vladimir Putin created an interdepartmental commission on historical education to "ensure a systematic and offensive approach to the issue of upholding the national interests of the Russian Federation related to the preservation of historical memory and the development of educational activities in the field of history" (TASS, 2021). Unlike the previous body designed to deal with this task-the Commission on Countering Attempts to Falsify History to the Detriment of the Interests of Russia-the new institution does not include members of the Federation Council and the State Duma, but involves officials from the Prosecutor General's Office, the Investigative Committee, and the Ministry of Internal Affairs.

The politicization of memory, especially around the (re)assessment of the causes and outcome of World War II, is already an established confrontational discourse. The securitization of the historical role of the USSR in the fight against Nazism is a long-standing process. From Moscow's point of view, the revision of these events threatens not only the national and state identity of Russia, but also the entire existing world order (Lavrov, 2019, p. 9). In this case, we can also talk about the "sustainable securitization" of this problem.

In conclusion, let us note once again that the success of securitization, according to Buzan and Wæver, depends on the actor's ability to convince the audience that a certain phenomenon poses a real threat. The argument with which the actor addresses the audience plays an important role in this case. In this regard, the Strategy is far from perfect. In fact, the long list of threats facing Russia may look convincing, but their abundance and variety can devalue their existential nature. There are also internal contradictions in the Strategy. For example, the aforementioned sanctions ("restrictive economic measures") against Russia are defined as a "negative factor" for its economy and as a threat for the quality of life of Russian people. However, such ambiguity is somehow consistent with the official rhetoric that the sanctions imposed against Russia 
do not cause serious damage to its economy but are directed against all its citizens.

The actual differences between the Strategy and reality are far more serious. While declaring, for example, the "consolidation of civil society around common values," which include "respect for family and confessional traditions," the authors of the Strategy seem to ignore the steady (since the peak year of 2011) decrease in the number of marriages in Russia and the unchanging number of divorces, comparable to the highest rates registered in Soviet times (Demographic Yearbook, 2019, p. 50). According to various estimates, the share of Orthodox believers in Russia, ranging from 56\% (ZIRCON) to $65 \%$ (FOM) (Zadorin and Khomyakova, 2019, p. 167), exceeds the share of Christians (mainly Catholics) in secular France (47\%), but is lower than the share of Catholics in Italy (69\%) and even more so than in Poland (86\%) (Eurobarometer, 2019, p. 229). However, in Russia, church services are attended relatively regularly (that is, at least once a month) by $13 \%$ (VTsIOM, 2019) to 19\% (Zadorin and Khomyakova, $2019,169)$ of the Orthodox believers, and only $2 \%$ observe all fasting requirements (VTsIOM, 2021). For comparison: in France, the share of Christians who regularly (that is, weekly) attend church services is 6\% (Statista, 2021a), in Italy, 22\% (CVX Italia, 2020) to 29\% (Statista, 2021b), and in Poland, 47\% (Statista 2021c).

In addition, the provisions of the Strategy stating that "there is a natural population growth and an increase in average life expectancy" in Russia are at odds with official statistics. According to the Rosstat state statistics agency, Russia's natural population decline has been continuing since 2016 (Demographic Yearbook, 2019, 16), and the average life expectancy in the country has dropped to the 2015 level due to the coronavirus epidemic (RBC, 2021). Disregard of such basic data concerning Russia's internal situation may cast doubt on its foreign policy.

In general, we can confidently conclude that the National Security Strategy of the Russian Federation and the discourse around it can, with certain reservations, be described and studied within the framework of the securitization theory developed by the Copenhagen School. Specific 
features of the Strategy, which go beyond the scope of this theory (an abundance of threats, the "sustainable securitization" effect), rather expand the researcher's task, pointing to new possible directions for developing the theory. The ambiguities and contradictions found in the document only add relevance to the research task as they can indicate both the peculiarities of methods used by the Russian authorities in working with information and the standards for presenting this information-in other words, the peculiarities of power discourse evolvement in Russia.

\section{References}

CVX Italia, 2020. Cattolici in Italia nel 2020: noi Cvx, nella Chiesa per esserci [Catholics in Italy in 2020: We, the Christian Life Community (CLC-CVX), Are Here in Church]. CVX Italia, 4 October [online]. Available at: www.cvxlms.it/ cattolici-in-italia-nel-2020-noi-cvx-nella-chiesa-per-esserci/ [Accessed 4 August 2021].

Demographic Yearbook, 2019. The Demographic Yearbook of Russia. Federal State Statistics Service. Moscow: Rosstat.

Eurobarometer, 2019. Special Eurobarometer 493. European Union: European Commission, September 2019 [online]. Available at: europa.eu/eurobarometer/ surveys/detail/2251 [Accessed 4 August 2021].

Lavrov, S., 2019. The World at a Crossroads and a System of International Relations for the Future. Russia in Global Affairs, 17(4), pp. 8-18. DOI: 10.31278/1810-6374-2019-17-4-8-18.

Makarychev, A., 2008. Security and the Return of the Political: The Critical Debates in Europe. Security Index: A Russian Journal on International Security, 14(2), pp. 21-34. DOI: 10.1080/19934270.2008.9756536.

Manning, B., 1979. The Congress, The Executive, and Intermestic Affairs. Foreign Affairs, 57(2), pp. 306-324.

McInnes, C. and Rushton, S., 2011. HIV/AIDS and Securitization Theory. European Journal of International Relations, 19(1).

Morozov, V., 2011. Bezopasnost' kak forma politicheskogo: o sekyuritizatsii i politizatsii [Security as a Form of the Political: Securitization and Politicization]. Polis. Political Studies, 3, pp. 24-35. 
RBC, 2021. Ozhidaemaya prodolzhitelnost' zhizni v Rossii v pandemiyu snizilas' na dva goda [Life Expectancy in Russia during the Pandemic Decreased by Two Years]. RBC.ru, 11 March [online]. Available at: www.rbc.ru/economics/11/03/ 2021/604a3c099a7947c4afb996b7 [Accessed 4 August 2021].

Risør, H., 2018. Civil Victimhood: Citizenship, Human Rights and Securitization in Post-Dictatorship Chile. Anthropological Theory, 18, pp. 271-295. DOI: $10.1177 / 1463499618777433$.

Statista, 2021a. Frequency with which Christians Go to Church or Temple in France in 2020. Statista [online]. Available at: www.statista.com/ statistics/1238643/church-temple-attendance-among-christians-france/ [Accessed 4 August 2021].

Statista, 2021b. Number of People Who Attend Religious Services at Least Once a Week in Italy from 2006 to 2019. Statista [online]. Available at: www.statista. com/statistics/576085/weekly-church-attendance-in-italy/ [Accessed 4 August 2021].

Statista, 2021c. Share of Believers and Participants in Religious Practices in Poland in 2020. Statista [online]. Available at: www.statista.com/ statistics/1133976/poland-declarations-of-faith-and-religious-practices/ [Accessed 4 August 2021].

Strategy, 2021. Strategiya natsionalnoi bezopasnosti Rossiiskoi Federatsii [National Security Strategy of the Russian Federation]. Kremlin.ru [online]. Available at: static.kremlin.ru/media/events/files/ru/QZw6hSk5z9gWq0plD1Z zmR5cER0g5tZC.pdf [Accessed 2 August 2021].

TASS, 2021. Putin postanovil sozdat' mezhvedomstvennuyu komissiyu po istoricheskomu prosvestcheniyu [Putin Decreed the Creation of an Interdepartmental Commission on Historical Education]. TASS, 30 July [online]. Available at: tass.ru/obschestvo/12028997 [Accessed 3 August 2021].

VTsIOM, 2019. Rozhdestvensky post-2019 [Christmas Fast 2019]. VTsIOM Russian Public Opinion Research Center, 29 November, [online]. Available at: wciom.ru/analytical-reviews/analiticheskii-obzor/rozhdestvenskij-post-2019 [Accessed 4 August 2021].

VTsIOM, 2021. Veliky post - 2021 [The Lent 2021]. VTsIOM - Russian Public Opinion Research Center, 15 March, [online]. Available at: wciom.ru/analyticalreviews/analiticheskii-obzor/velikii-post-2021 [Accessed 4 August 2021]. 
Webber, M. and Sperling, J., 2017, NATO and the Ukraine Crisis: Collective Securitisation. European Journal of International Security, 2(1), pp. 19-46. DOI: https://doi.org/10.1017/eis.2016.17.

Zadorin I. and Khomyakova A., 2019. Religioznaya samoidentifikatsiya respondentov v massovykh oprosah: chto stoit za deklaratsiyami? [Religious Self-Identification of Respondents in Mass Surveys: What Is Behind Declared Religiosity?]. Politeia, 94(3), pp. 161-184. DOI: 10.30570/2078-5089-2019-943-161-184. 